\title{
一鍺言一
}

聴覚脳幹系が高位中枢から遠心性制御を受けているととはよく知られている。電気生理 学的或いは解剖学的研究により螖牛神経核に Noradrenaline系が抑制性に作用する報告があ る。我々は種々のNoradrenaline系薬物投与時のABR波形を記録、検討してきたか、今回は 系薬物（主として $\alpha$ 2-Agonistの Clonidine）投与による興味ある知見について報告する。

一方法一

鼓膜所見及びプライエル反射が正常な体重 $300 \mathrm{gr}$ 前後のSLC-Wistar系ラット12匹使用した。麻酔は $\alpha$-Chloralose $80 \mathrm{mg} / \mathrm{kg}$ 腹胿内投与、電極は硬膜上に 2 本の銀ボール電極をいずれす頭蓋正中線上で、1 本はブレグマとラムダ縫合の中点に、他の 1 本はブ レグマ檤合の吻側 $3 \mathrm{~mm}$ の位置に植え込んだ。

スピーカー（AIWA SC-51）の $10 \mathrm{~cm}$ 前方に両側耳 介が来る様にラットを固定し、8KHz、100 $\mathrm{k} \sec の ク$ リック音を音王60〜80dBで毎秒 2 回. (Dana Japan DA-502 A) 、計200回（日本光電ATAC 150）聞かせ た。実験中体温は $37^{\circ} \mathrm{C}$ 保持し、Clonidineは頸静脈

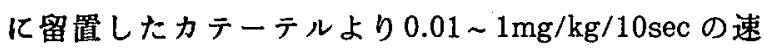
度で注入した。コントロールには生食の静注を行な った。

一結果 -

$\triangle$ 覚醒時及び $\alpha$-Chloralose麻酔下でのABRとの間に は潜時、波形とも大きな差はない。（図 1)

$\triangle$ 上記条件で記録した波形は 7〜9個の連続する陽 性波から成り、再現性の高い 7 波までの潜時の平均 值及び標準誤差を表 1 亿示す。

$\triangle$ Clonidine投与によるABRの変化（図 2 ）

○ $0.01 \mathrm{mg} / \mathrm{kg}$ 投与ではほとんど変化はない。

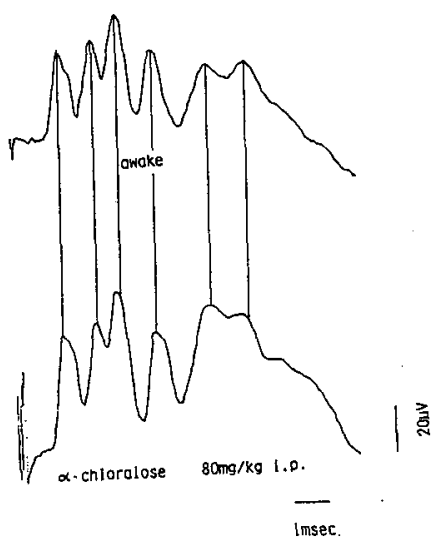

図 1

LATENCY OF EACH PEAK IN RAT ABR

\begin{tabular}{ccc}
\hline peak & mean & latency $(\mathrm{m} \mathrm{sec})$ \\
\hline P 1 & 1.47 & 0.03 \\
P 2 & 2.43 & 0.04 \\
P 3 & 3.08 & 0.06 \\
P 4 & 4.17 & 0.08 \\
P 5 & 5.58 & 0.09 \\
P 6 & 6.63 & 0.08 \\
P 7 & 8.06 & 0.10
\end{tabular}

表 1

O0.1mg/kg投与では 2 波の低下は見られるが、峰分れが見られるものああれば見られな いものあある。

○0.5mg/kg投与では 2 波の峰分れと 4 波の低下を見る。

$\mathrm{O} .1 \mathrm{mg} / \mathrm{kg}$ 投与では、 $0.5 \mathrm{mg} / \mathrm{kg}$ 投与時の変化がより著明となり、 5 波以降の陽性波の独立 性加疎外さ机る。

○Clonidineの量を增量しても、1 波及び 3 波のAmplitudeはほとんど保たれている。 ○潜時について一波形、Amplitudeの保たれている1波、3 波はほとんど変化しない。 2 波では峰分れの後半成分は投与前の潜時とほほ一致している。4 波以降の陽性波につ 
いては規則性がない。

$\triangle$ Yohimbine投与による波形の回復（図 3 ）

Clonidine投与によるABRの変化は $\alpha-2$ Antagonist のYohimbine $2 \mathrm{mg} / \mathrm{kg}$ 投与により速やかに回復する。 即ち 2 波の後半成分の回復、 4 波の增大傾向をみ る。しかしClonidine投与で変化した 5 波以降の波 形パターンは回復しない。

尚、Yohimbineを前に投与してもABRに変化はほ とんど見られない。

$\triangle$ Hexamthonium 投与時の ABR

この様な $\mathrm{ABR}$ 波形の変化がClonidineの中枢性降圧 作用の二次的変化の可能性むおり、他の降圧剂之 して神経節遮断薬を投与した処、ABRにはほとん ど変化は見られない。

\section{一考按 -}

Clonidineは $\alpha-2$ receptor刺激薬でその作用は種々 あるか、主なものとして視床下部血管中枢抑制によ る血圧降下作用、及び中枢性鎮痛鎮静作用が挙げら れる。視床下部、孤束核、縫線核、青斑核、大脳辺 縁系等に $\alpha-2$ receptor が多く存在するとの事実から Clonidineによる薬理作用と中枢でのその責任部位の 関連性が対比証明されている。

今回得られたClonidine投与で 2 波、4 波のAmplitudeの低下を見、Yohimbine投与で回復するという知 見より、これらの陽性波を構成する脳幹中継核に $\alpha-$ 2 receptor が存在する。換言すれば $\alpha-2$ typeの遠心性 制御が聴覚系脳幹レベルに働いているものと考える。

現在脳幹諸核からの聴性誘発電位を同時記録して a $0.5 \mathrm{mg} / \mathrm{kg} \mathrm{t,v.}$ ClonidineによるABR変化の機序を追求している。又、 $\alpha-1$ typeの薬物作用についても検討中である。
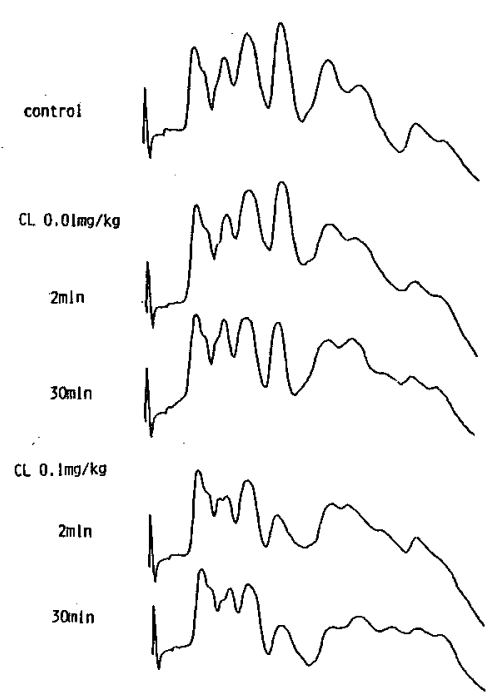

C.. Ing $/ \mathrm{kg}$

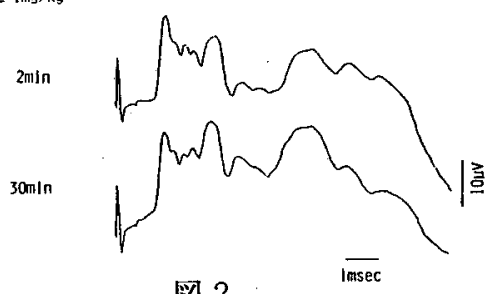

図 2

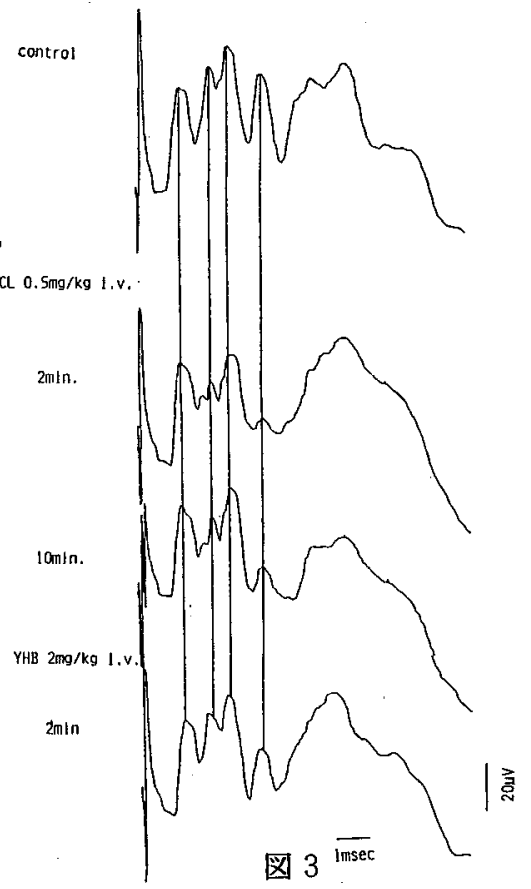

